\title{
DOES LEGAL TRADITION AFFECT COMPETITION POLICY PERFORMANCE?
}

\section{A. E. Rodriguez}

During the early 1990's, in the early days of the worldwide competition policy boom, Spencer Waller and Joshua Newberg argued that difficulties inherent in grafting common law concepts-such as antitrust-onto non common law traditions would undermine the administration of competition law in non common law tradition countries. Recent independent survey data on the performance of competition programs in 102 nations shows deplorable differences in performance, lending some weight to the WallerNewberg thesis.

This article tests whether differences in legal tradition contributes to the observed variance in competition agency performance.

A careful understanding of the influence of legal tradition and other factors underscoring the relevance, shortcomings and problems of competition policy performance are useful for determining whether competition programs should be at all reproduced elsewhere, whether they should be modified prior to adoption or whether they should be adopted verbatim. Familiarity with performance factors is also useful both for program administration and program sequencing. Comparative examinations of competition programs enable decision-makers to properly allocate resources and to address policy issues.

A. E. Rodriguez is in the Department of Economics \& Finance, at the University of New Haven, West Haven, Connecticut. 
The estimated model is a two-stage least-squares cross-section analysis between competition policy performance and various control variables, including the presence of a common law tradition. Limitations on the availability of control and instrumental variables, reduces the data set from 102 to 82 nations.

Succinctly, after accounting for other explanatory variables such as gross domestic product per capita, foreign direct investment, imports, physical size, the level of corruption, and national experience with a modern antitrust law, one can attribute statistical significance to historical legal tradition as established by the Waller-Newberg hypothesis.

$* \quad * \quad * \quad * \quad *$

\section{INTRODUCTION AND OVERVIEW}

Over the last two decades, as countries around the world adopted competition policy programs (Fox, Sullivan, and Peritz, 2004), the debate over the soundness of this policy prescription preoccupied scholars and practitioners (Boner and Krueger, 1991; Scherer, 1994; and Richardson and Graham, 1997). One of the most engaging arguments examined possible difficulties resulting from grafting or incorporating antitrust legal concepts drawn from a common-law tradition into countries characterized by a civil-law tradition. To some, this was a troubling mismatch; one that could prove to be sufficiently difficult so as to preclude the effective functioning of the individual competition programs (Newberg 1994; Waller 1994).

These concerns were not unfounded. Competition agency performance has been erratic and varied. For example, Table I, below, displays the average score of various country groupings drawn from a multinational survey assessing national competition policy performance (World Economic Forum, 2004). 
Table I

Competition Policy Performance by Regional Grouping, Year 2003

\begin{tabular}{lcc}
\hline Group & Average Score & $\begin{array}{c}\text { Number of Countries } \\
\text { in Group }\end{array}$ \\
\hline Africa & 3.44 & 25 \\
Asia \& Middle East & 4.06 & 14 \\
Europe & 3.58 & 15 \\
Latin America & 3.16 & 20 \\
OECD & 5.06 & 25 \\
Entire Group of Countries in Data Set & 3.96 & 102 \\
\hline
\end{tabular}

The World Economic Forum surveyed businessmen to rate the effectiveness of the antitrust policy in their particular country, asking them to rate "antimonopoly" policy from " $1=$ lax and not effective and promoting competition" to " $7=$ effectively promotes competition".

Three of the regional groupings assembled in the table above, encompassing 60 countries, display below-average performance. Some groups display deplorable performance; the difference between the Latin America's countries' group mean-the lowest of the groupings-and the OECD countries' group mean-the highest-is almost 2 standard deviations.

The performance dissimilarity is even more marked across income groupings. Table II below lists performance scores across three income groupings.

Table II

Competition Policy Performance by Income Level, Year 2003

\begin{tabular}{lcc}
\hline Group & Average Score & $\begin{array}{c}\text { Number of Countries } \\
\text { in Group }\end{array}$ \\
\hline Low-income & 3.19 & 33 \\
Middle-Income & 3.66 & 38 \\
High-Income & 5.14 & 31 \\
Entire Group of Countries in Data Set & 3.96 & 102 \\
\hline
\end{tabular}


The variation in performance between low-income and highincome countries is approximately two standard deviations.

Understanding the relevance of factors affecting agency and program performance (Kovacic, 2001, 2004) has far reaching implications-both scholarly and practical. First, awareness of the relevance, shortcomings and problems of the factors underscoring performance are useful for determining whether competition program should be at all reproduced elsewhere, whether they should be modified prior to adoption or whether they should be adopted verbatim.

Second, understanding the influence and relevance of a nation's legal tradition in the practice of antitrust might be useful in determining how well the novel competition programs are working in practice, i.e. whether they are having their intended salutary effects.

Third, knowledge of the determinants of performance can be used to construct better theories about the operation of competition in the local jurisdiction, the relationship between the competition policy approach and larger economic or social development goals, and the impacts of various kinds of intervention and reform. Empirical work is useful in generating and refining good theories. Competition theories, in turn, influence both the design of specific reform programs and overall reform strategy.

Fourth, ongoing interest in international collaboration and concerns over alleged increases in transnational anticompetitive practices places domestic competition agencies at the center of these efforts (e.g., Davidow and Shapiro, 2003; Hoekman and Mavroidis, 2003; Fox, 2003; and Epstein and Greve, 2004). Obviously, under-par performers jeopardize the success of the collective initiative. The existence and persistence of the observed performance gap must be of concern to multi-jurisdictional cooperation advocates and to competition advocates in general.

This article examines whether national legal tradition is a factor underscoring the variance in competition policy performance-the performance gap-as documented in the two tables above and as the 
Waller-Newberg hypothesis holds. There are many distinguishing elements particular to the common law: it constitutes the fields of laws that have been created largely by judges as the by-product of deciding cases rather than by legislatures (Posner, 1992); reliance on precedent, the doctrine of stare decisis; the reliance on earlier decisions of other courts; the incorporation or adoption of new precedents to the stock of legal capital through litigation; its adversarial constitution; its reliance on experts to assist the trier-of-fact; differing and shifting burdens of proof.

This study specifies a linear model relating competition agency performance to national legal tradition and includes several control variables drawn from theory and from previous research (which include the categorical variables in Tables I and II, above). Succinctly, once we account for other variables that affect competition policy performance, we document the relevance of the Waller-Newberg hypothesis; a finding of no statistical significance on the estimated coefficient of the legal tradition variable refutes the hypothesis. The empirical test presented here is not able to identify the particular element or elements of the common law that account for the statistical significance of the hypothesis: this is left for further work.

The article is organized as follows. The following section presents a review of the Waller-Newberg hypothesis and the literature on legal convergence in antitrust. Section three discusses the evidence on competition policy performance. In section four we offer statistical tests of the Waller-Newberg hypothesis and a discussion of the results obtained. The last section concludes.

\section{A REVIEW OF THE CONVERGENCE LITERATURE AND THE WALLER-NEWBERG HYPOTHESIS}

Professor Spencer Waller argued that neither the transfer of existing national laws nor the international harmonization of 
competition law offered any realistic prospect for the desired outcomes (Waller, 1994). United States antitrust law represents a unique social and historical construct of events and themes that may not be easily grafted into a foreign legal setting. Moreover, antitrust enforcement may be significantly more difficult for reforming economies. This reflects the danger of what one might call the "transferability problem". It neglects the cultural, institutional, economic, and political obstacles to the implementation of an antitrust policy.

Professor Joshua Newberg raised two concerns linked specifically to the applicability of antitrust policy in Mexico but that reflected issues present in other economies in transition (Newberg, 1994). The first concerned the novelty of antitrust issues. Mexico has no antitrust tradition comparable to the decades-long U.S. heritage, thus it possess no coherent and relatively predictable modes of legal analysis for antitrust cases. A second concern arises from the legal conventions of non-common law system-a civil law system, for example. Historically, in contrast to the common law system, civil case law retains no precedential value.

Similarly, judges and administrative agencies are circumscribed from commenting on or influencing the development of legal doctrines (Merryman, 1985). Others raised related concerns. Peter Schuck and Robert Litan recount the "chastening attempt" to develop a program of regulatory policy in Peru (Schuck and Litan, 1986). Then U.S. Federal Trade Commission Chairman, Robert Pitofsky noted that: "You can't expect countries at such different levels of economic development to have all the same answers to competition policy issues" (US FTC, 1996, 15).

There are a number of idiosyncratic elements that may preclude American antitrust learning from functioning as effectively in different settings as they have in the United States. A deep historical distrust of corporate or business power or at times bigness itself is historically reflected in the antitrust laws of the United States. Comanor argued that to a large extent, two sets of 
interests-the fear of corporate power and the search for corporate legitimacy-provide the critical support for the American antitrust laws (Comanor, 1982). Of course, the de-centralization of decisionmaking, the dispersion of power, and a higher standard of business ethics, as legitimate social objectives, may lay equal claim to guiding policy (Pitofsky, 1979).

The implementation of competition policy in other countries may turn out to be an example of what Dolowitz and Marsh (2000) call "uninformed transfer," whereby a country borrows a policy from elsewhere but is ignorant of how it truly operates. In this case, the adoption of largely western-style competition policy programs and the emphasis on a (seemingly) common set of behavioral responses to competition policies. A foreign law and its administration will possibly reflect the traditions, jurisprudence, cultural institutions; but those of another nation, not necessarily of the recipient country.

For example, few would argue that the present state of antitrust law in the United States is heavily influenced by modern day microeconomics-which largely recommends a far less interventionist role for the state in the enforcement of the competition laws (Kovacic 2003). Importantly, this paradigm arose for many reasons including an inherent receptiveness of the common law to evolution in economics know-how and the presence of effective institutions gathering relevant commentary and jurisprudence; institutions such as think-tanks, academic departments and a thriving culture of critical thinking expressed through manifold outlets: books, journals, working papers, white papers, speeches, to name a few. One finds few of these factors present in countries adopting competition policy programs-yet the operation of an efficient competition policy requires many of these factors (Kovacic, 2001).

By implication, a competition policy, to be effective, must reflect a country's institutional and economic realities. Uninformed transfer may very well plague the implementation of 
competition policy in developing countries. Thus, although there appears to be a similarity of functions between the antitrust agencies in developed market economies and those in economies recently adopting competition programs, these similarities are largely superficial; in reality, there are substantial disparities in their underlying structures derived from differences embodied in legal traditions as proffered by Waller and Newberg that prevent the easy alignment of competition policies.

Cassey Lee (2004) offered an initial empirical assessment of the relevance of the common law, concluding that legal tradition is not significantly related to performance of competition law enforcement. Unfortunately, Lee's work was limited in scope and robustness; it contained no control variables aside from national income and relied on a smaller data set than the one used here. Michael Krakowski (2005) also examines competition policy performance using the same survey data; however, the author does not examine the relevance of national legal tradition.

Recent finance scholarship offers incidental support for the Waller-Newberg thesis. Much of the research in this area finds that countries with legal systems based on the common law have more developed financial markets than civil-law countries (La Porta et al., 1997, 1998). Mahoney (2001) clarifies the causality, arguing that finance is not the sole, or principal, channel through which legal origin affects growth; he finds that common-law countries have experienced faster economic growth than civil-law countries. At their core, these findings suggest that the common law produces faster growth through greater security of property and contract rights (Levine, 2005).

\section{EXPLAINING THE PERFORMANCE GAP}

Why does there exist such dramatic variance in competition policy performance? After all, antitrust is firmly grounded in conventional economics (Kovacic and Shapiro, 2000) and a 
sufficiently well understood methodology (Gellhorn, Kovacic, and Calkins, 2004). Importantly, with varying degrees of effort and financial assistance, competition policy advocates have worked hard to recommend the same core set of policy goals and objectives to developing and transition economies (Palim, 1998; UNCTAD, 2004; OECD, 2002; Lee, 2004). Competition policy proscriptions adopted by most countries reflect common prohibitions against price-fixing, and horizontal cartels (OECD, 1998; UNCTAD, 2000).

But even if the competition programs had been identical in all their aspects across all nations it would not ensure that programs would be administered uniformly. One would naturally expect some performance heterogeneity. Varying consumer and producer interests and their respective ability to condition or influence the administration of competition policy varies across states; government regulation would reflect these preferences, so not all countries would choose the same administrative path and intensity even if they were all privy to the same toolkit and had comparable administrative abilities. Thus, one would expect variance to exist if only as a result of variations in instrument preferences or political will.

Natural variation aside, competition programs are not identical in important aspects. Many competition policy-enabling laws display multiple goals despite the presence of a set of objectives common to all laws. A multiplicity of goals could jeopardize an agency's general performance if it falls short in achieving one of its goals despite adequate, or above average performance in its other goals.

The conventional approach to competition policy turns on a set of rules that represent explicit prohibitions on competitive behavior and particular business practices, proscribed because they reduce consumer welfare. If violated, the rules allow prosecution of those infringing. The competition agencies are formally tasked with enforcing laws that proscribe anticompetitive practices. 
Several of the recently adopted competition policy and competition enforcement agencies came about in response to the growing disenchantment with the seeming meager successes of deregulation and liberalization programs of the late 1980s and 1990s. These competition programs and the associated enforcement agencies were ostensibly aimed at entrenched dominant firms and private monopolies. These firms were perceived to be compromising competitive vigor in the newly reformed economies and thereby responsible for delaying the much anticipated and widely heralded gains promised by free markets, privatization and deregulation. Competition agencies, armed with clear legislation delineating the competitive rules of the game were considered vital in pushing back anticompetitive practices.

But in addition to the conventional efficiency and resource allocation objective of traditional antitrust policy, competition policy proponents in the multilateral agencies, financial institutions both in developing and donor countries have often favored a multiplicity of goals for competition. Indeed, jurisdictions have embraced any number of explicit and implicit policy objectives. The World Trade Organization, for example, recently listed "some further examples of objectives from different competition policy instruments" (WTO, 2004):

- maintenance of the competitive process or of free competition;

- freedom of trade, freedom of choice and access to markets;

- freedom of individual action;

- securing economic freedom;

- lessening the adverse effects of government intervention in the marketplace;

- prevention of abuse of economic power;

- achievement of economic efficiency.

Equity and social considerations are also explicitly stated competition policy goals (Fox, 2000). South Africa's competition 
code, for example, embraces racial equality; many other countries explicitly protect and nurture small businesses. As a result, and not infrequently, the competition policy goals of one country may be at odds with those of a neighboring country. Not infrequently, multiple competition policy objectives within the same country appear to be seemingly at odds with each other. For example, efficiency-enhancing considerations derived from economies of scale and buyer power would support the presence of a Wal-Mart type mega-store in a particular jurisdiction and raise no objection from the competition agency. A mega-store commands economies of scale that typically translate into significant price concessions that get passed-on to consumers. The lowered prices and wider inventory often wreak havoc over existing small business as consumers opt to patronize the mega-store. The actions of a competition agency based on discharging an efficiency-based agenda would be directly contrary to what it would do if it is simultaneously obliged to nurture and protect small and medium-sized business.

There are many reasons why one would expect nations favored by the common law to inherit conditions and features that convey performance advantages to antitrust agencies enforcing an antitrust law: several contextual and technical conditions are proffered below, amidst the explanatory variable selection discussion.

The foundations of the proposition that the common law will beget comparative advantage to the administration of competition policy programs lies with the general thesis that the common law could best be understood as a set of rules designed to maximize economic efficiency-the joint value of interacting activities, a thesis that originates with Posner in the early 1970s (Posner, 1992). As a result, the common-law process is capable of generating efficient competition rules (Priest 1973; Rubin, 1973). Thus, one suspects that common law may be more receptive to the evolutionary nature of economic theory and practice than are non-common law traditions where the need for theory and 
evolving interpretation is circumscribed by design, but a more refined explanation of the differences between legal traditions is beyond the scope of this article.

\section{Explanatory Variables}

There are exogenous reasons that would plausibly explain the performance gap. We turn to a discussion of their expected impact in this section.

\section{Legal Tradition}

Recent finance scholarship finds that countries with legal systems based on the common law have more developed financial markets than countries with systems based on traditions other than civil-law. Mahoney (2001), arguing that finance is not the sole, or principal, channel through which legal origin affects growth, finds that common-law countries have experienced faster economic growth than civil-law countries. At their core, these findings suggest that the common law produces faster growth through greater security of property and contract rights.

The Waller-Newberg hypothesis argues that there are inherent difficulties in transferring modern antimonopoly practices to jurisdictions with legal traditions different from common law traditions. The absence of an antimonopoly tradition and jurisprudence fails to provide the legal structure necessary to support a vibrant and dynamic competition policy and necessarily impairs the functioning of an effective competition policy.

Importantly, the thesis holds that a legal tradition that takes no formal notice of legal precedent would render the competition environment less predictable. Together with the fact that judges are unable to comment on their decisions and enrich the relevant legal doctrine would embed fundamental uncertainties in the system and render it less appealing to the private sector. Thus, to the extent these observations are applicable to competition law we 
expect those agencies in common law countries to perform better than those in non common law countries.

However, there are counterarguments that would negate the seeming advantages of common-law countries. Because competition policy is firmly grounded in mainstream economics, the core learning and administration of policy in non-common law countries is unlikely to vary from common law jurisdictions (Ghoneim, 2003). In addition, although competition agencies in civil-law jurisdictions are not bound by legal precedent, many have adopted a policy of institutional deference to their own decisions to provide guidance and administrative clarity to private parties and thereby minimize transactional uncertainty. Thus, to the extent that economics offers consistent decision-making and the agencies respect their own internal precedents the potential for procedural pitfalls noted by Professors Waller and Newburg can, in principle, be overcome.

\section{National Income}

One would expect affluence to account for a significant portion of the performance gap (Lee, 2004; Palim, 1998). After all, richer countries are more likely to afford the professional administration of their law enforcement system and the competition laws in particular (Posner, 1998). In addition, much recent empirical literature shows a strong positive correlation between the quality of a nation's governance institutions and income per capita (Kaufman, Kray, and Mastruzzi, 2005).

However, because competition policy programs in developing and transition economies have been seeded with considerable direct and indirect assistance (FTC, 2002), national affluence may not be an explanatory factor. On the other hand, it is primarily in the low and middle-income economies where the competition enforcement agency has been burdened with the multiplicity of competition policy goals; this influence can be isolated controlling for income groupings. 


\section{Experience}

Many economies have had little or no experience with market driven competition before adopting a competition law and a competition enforcement agency. In some jurisdictions, there was scarce understanding of the role of the agency and often no relevant jurisprudence to accommodate the role of an agency. Understandably, efficient public administration of a competition policy is a skill that requires time and one may expect performance to be positively correlated with years of experience. Many countries have had anti-monopoly laws in the books for many years.

However, their use and effect remained largely dormant because of differences between preferred economic paradigms at the time which often frowned upon market-based policies. Many of these nations have revised their competition legislation to adapt their administration to conform to the objectives of pro-market reforms and liberalization programs. In these cases, in the empirical work presented below, the "beginning" year was taken to be the year when the competition law was implemented.

In a number of instances, competition legislation proceeded over several years, accommodating revisions and other changes; these changes were not accounted for in this study. The information on year of adoption of the relevant competition law is obtained from the survey of competition laws by the International Bar Association's Global Competition Forum (http://www.globalcompetitionforum.org).

\section{Corruption}

Poor agency performance may be attributed to corruption, either at the enforcement agency, or in the business milieu, or both. Commentators have argued that antitrust laws alter the relative cost between private cartelization and government-sponsored cartelization. This suggests that shortly after the adoption of a competition policy and assuming the agency is effective and active, we would observe an increase in rent-seeking efforts as 
interest groups maneuver to protect existing anticompetitive rents without running afoul of the agency. Strictly speaking, this is not corruption.

Unfortunately, acts considered corrupt are sufficiently amorphous, especially those occurring in nations with poor governance structures or those nations historically known to coddle corruption, that it is difficult to distinguish legitimate, and legal, rentseeking, lobbying. In this environment of rampant and historical corruption, it is possible that a domestic agency observer would perceive the efforts of the agency as inconsequential and wrongly assign it poor marks in tallying a corruption "survey." In fact the agency cannot be faulted for what is necessarily a broader problem of utilizing the wrong tool for the wrong problem. A law enforcement agency is unsuited to challenge legitimate and perfectly, albeit anticompetitive, legal lobbying efforts (Rodriguez and Williams, 1995). Thus, one expects, ex ante, to find a corruption measure or indicator a significant factor in determining agency performance without necessarily impugning the competition agency.

The continued presence of institutions designed to advance close collaboration between the private sector and the government, and other similar factors, rendered competition agencies susceptible to capture or neutralization in many nations. Carolyn Brezinski (1994), for example, states that

"Each of these ... [Eastern European] antimonopoly laws were designed to accommodate the characteristics of the post-socialist economies, such as the high degree of monopolization and severe problems of market measurement. The vague language of the laws and the discretion of the competition authorities to shift their enforcement efforts to comprise means of introducing and protecting competition in these highly transitional economies."

Capture, of course proceeds from a close alignment of the incentives of the competition agency and the executive or those 
of private sector groups. Similarly, the competition agency can be easily neutralized if attempts to proscribe cartelization and other anticompetitive horizontal practices are circumvented by the erection of non-tariff barriers.

Size

It has been argued repeatedly that the best remedy for anticompetitive practices is free and unfettered trade, a remedy even more applicable and salutary in small economies. However, there have been any number of commentators who have carefully examined small economies and concluded that attributes exclusive to small economies render them immune to the benefits of increased trade (Briguglio and Kaminarides, 1993; Gal, 2001a, 2001b). For example, trade has little impact on non-tradeables. Significant participants in local markets are likely to have historically accumulated market power preserved by regulatory and tariff barriers placed by friendly governments. In principle, the undoing of regulatory barriers to entry of the new free-market regime will result in domestic challenges that will beget competition. In reality, the power and influence of entrenched power groups is unlikely to abate with regulatory changes.

Another key proposition of free-trade skeptics is that small economies can support fewer firms. Logically, only a few firms are capable of achieving the minimum efficient scale in a small closed economy given the modest levels of demand (Boza, 2003; Evans and Hughes, 2003). The conventional counterargument points out that eliminating tariffs and other barriers to trade naturally leads to broader antitrust geographic markets and the potential for growth at the same time as consumers gain from the resulting lower prices and increased choice. Obviously, the small-economy firms can enter the much larger geographic market that resulted from open borders and proceed to compete vigorously. But to achieve the larger optimal scale associate with the now broader geographic market requires time and capital. Because the small 
economy firm has its domestic constituency, it typically finds it less costly to protect itself and lobby for non-tariff barriers or any similar protectionist measure rather than compete.

\section{Imports}

More intense competition by way of increased imports or foreign direct investment is likely to reduce or ameliorate the tasks of the competition agency (Wacziarg and Welch, 2003). Liberal trade policy had long been defended by the proposition that imports and entry discipline domestic producers' market power to raise prices. In broad geographic markets, international competition forces domestic firms to be competitive. One would expect a variable controlling for the level of imports, or the level of foreign direct investment to be influential in explaining comparative agency performance. The best performing competition agencies will be found in the least competitive economies where imports provide no discipline on competition leaving ample room for market power abuses. However, the converse may also be true: the lack of imports enables agencies to perform better because it reduces the relevant markets observed by the enforcement agencies thereby strengthening an agency's prospective cases.

Having discussed variables with likely bearing on the competition policy performance question, as well as the direction of their expected effect, an econometric model examining their relevance is proposed and evaluated in the next section.

\section{COMPETITION AGENCY PERFORMANCE: CROSS-COUNTRY EVIDENCE}

In this section we appraise the influence of the various explanatory variables discussed above on competition agency performance by assuming the existence of a linear relationship between independent explanatory variables and a dependent variablecompetition policy performance; the formulation includes a 
variable reflecting a nation's legal tradition among the explanatory variables.

We begin with the base model specified below

(1) PERFORMANCE $\mathrm{i}_{\mathrm{i}}=\alpha_{\mathrm{i}}+\beta_{1} \mathrm{COMMMON} \mathrm{LAW}_{\mathrm{i}}$

and examine the relevance and importance of legal tradition on the observed variance in agency performance; i indexes 102 countries in the sample. Using ordinary least squares regression the model estimates the parameters characterizing the relationship between competition policy performance (PERFORMANCE) and national legal tradition (COMMONLAW).

As in Mahoney (2001), non-common law countries were collapsed into one single set; indeed, drawing a distinction between the civil-law subfamilies appears to be a post-hoc rationalization. In fact, because most of the civil-law subfamily countries are in economically advanced Western Europe, treating them together, contained within the non-common law group, entails a bias that makes the civil-law look better. Accordingly, COMMON LAW is a binary variable controlling whether a nation is characterized by the common law. Data sources and treatment of all variables can be found in a data appendix to this article.

An augmented regression that contains variables segmenting the data into income levels (LOW-INCOME and MIDDLEINCOME) examines whether the Waller-Newberg hypothesis holds across three mutually exclusive income-level groupings. This latter formulation controls for a possible omitted variable problem: specifically one that accounts for the association between a possible multiplicity of goals in competition policy performance noted in the text above and low and middle income countries. 


$$
\begin{aligned}
\text { PERFORMANCE }_{\mathrm{i}}= & \alpha_{\mathrm{i}}+\beta_{1} \mathrm{COMMMON} \mathrm{LAW}_{i} \\
& +\beta_{2} \mathrm{LOW}-\mathrm{INCOME}_{\mathrm{i}}+ \\
& \beta_{3} \text { MIDDLE }-\mathrm{INCOME}+\varepsilon_{\mathrm{i}}
\end{aligned}
$$

Results from both regressions are presented in Table III below.

Legal tradition is significant in the base regression at the 90 percent level suggesting there is some merit to the WallerNewberg hypothesis. The results of the second regression and associated t-statistics are shown in column four. The coefficient estimates are highly significant and indicate that the WallerNewberg hypothesis strongly holds differentially controlling for income. Tests for difference in cross-effects-specifically, for cross-dummies between common law and low-income and common-law and middle income-were not significant (the results have been omitted to conserve space). In fact, agencies in nations with a common-law tradition unequivocally display better performance than those agencies in non-common law nations. The increase attributable to the common law tradition is presented in Table IV below.

Table III

Base Model Results

\begin{tabular}{lcccc}
\hline Explanatory Variable & Coefficient Estimates & t-stat & Coefficient Estimates & t-stat \\
\hline$(1)$ & $(2)$ & $(3)$ & $(4)$ & $(5)$ \\
Constant & $3.846^{* *}$ & 32.54 & $4.978^{* *}$ & 41.73 \\
Common-Law & $0.4076^{*}$ & 1.81 & $0.496^{* *}$ & 3.42 \\
Low-Income & & -2.007 & -13.03 \\
Middle-Income & & -1.36 & -8.96 \\
r2 & 0.0316 & 0.657 & \\
F-stat & 3.27 & 62.68 & \\
Number of observations & 102 & \multicolumn{3}{c}{102} \\
\hline
\end{tabular}

${ }^{* *}$ represents significance at the $95 \%$ level or above; ${ }^{*}$ represents significance at the $90 \%$ level. 
Table IV

Difference to Income-Group Mean (as \% of Standard Error)

\begin{tabular}{lcc}
\hline Income Group & Common-Law Tradition & Non Common-Law Tradition \\
\hline Low & $47 \%$ & $-34 \%$ \\
Middle & $75 \%$ & $-7 \%$ \\
High & $55 \%$ & $-28 \%$ \\
\hline
\end{tabular}

To examine performance across the cross section controlling for exogenous variables other than legal tradition and income groups we specify the following model:

(3) PERFORMANCE $_{\mathrm{i}}=\alpha+\beta_{1}$ COMMMON LAW $_{\mathrm{i}}$

$$
\begin{aligned}
& +\beta_{2} \text { LOW-INCOME } \mathrm{i}_{\mathrm{i}}+\beta_{3} \text { MIDDLE } \\
& - \text { INCOME } \beta_{4} \text { CORRUPTIONL }_{\mathrm{i}} \\
& +\beta_{5} \text { LN IMPORTS }_{\mathrm{i}} \\
& +\beta_{6} \text { EXPERIENCE }_{\mathrm{i}} \\
& +\beta_{7} \mathrm{LN} \mathrm{SIZE}_{\mathrm{i}}+\varepsilon_{\mathrm{i}}
\end{aligned}
$$

where i indexes countries in the sample, The model examines the relationship between competition policy performance (PERFORMANCE) and national legal tradition (COMMONLAW); control variables include: binary variables separating nations into GDP per capita levels (LOW-INCOME, MIDDLE-INCOME, HIGH-INCOME); national experience with a modern competition law (EXPERIENCE), a variable that controls for the effect of trade and investment on competition (IMPORTS), a variable that controls for the physical size of a nation (SIZE) and the corruption metric described in the previous section (CORRUPTION). GDP per capita, imports and size were entered in natural logarithms. 
Our focus is on levels of income per capita rather than income per capita growth rates (Hall \& Jones, 1999). Income per capita in levels is more likely to capture fundamental cross-country differences in consumption and thereby in welfare and affluence levels and the ability to afford a competition agency. Further, the growth literature predicts that in the long-run all countries should grow at the same rate; thus observed cross-country differences in growth are transitory (Barro and Sala-i-Martin, 1992; Mankiw, Romer, and Weil, 1992).

Ordinary least squares and two stage least square estimates of the model coefficients are presented in the table below. Two-stage least squares estimation reflects concerns over the possible simultaneity of the competition performance variable and the corruption variable. A perceptions-based measure of antitrust performance such as the one used here is potentially subject to a number of biases. One common critique argues that survey respondents-perhaps unwittingly-confound correlation and causality; i.e. that corruption and competition policy performance may be jointly determined (Glaeser et al., 2004). This simultaneity precludes interpreting corruption as a causative factor.

Perceptions of competition policy governance may be biased (favorably) in countries where imports are greater because respondents view the importing success of the country or its ability to attract foreign direct investment as evidence that competition policy performance is good-regardless of the actual operational impact of the competition agency. This type of bias has been called a "halo effect." One can imagine a similar bias associating countries characterized by scant import vigor with poor competition policy performance. Moreover, since corruption is only imperfectly measured the OLS estimates suffer from attenuation bias as well as simultaneity bias.

I use ethnic fractionalization data as an instrument for the corruption perceptions variable. Alesina et al., (2003) and Fearon (2003) argue that societies that are more ethnically or 
linguistically fractionalized have more corrupt governments, largely because bureaucrats may have larger incentives to embezzle money to favor members of their own group. It seems reasonable to assume that ethnic fractionalization is uncorrelated with the disturbance in the performance equation because the degree of ethnic fractionalization is determined, for the most part, by historical colonial practices of politically segmenting countries with little regard to ethnic group presence.

\section{RESULTS}

The second column of Table $\mathrm{V}$ below provides ordinary least squares estimates of the extended model coefficients; the fourth column provides comparable two-stage least squares results.

The common law binary variable which identifies jurisdictions characterized by a common law tradition remains statistically

Table V

Extended Model Regression Results

\begin{tabular}{lcccc}
\hline $\begin{array}{l}\text { Explanatory } \\
\text { Variable }\end{array}$ & $\begin{array}{c}\text { OLS Coefficient } \\
\text { Estimates }\end{array}$ & t-stat & $\begin{array}{c}\text { 2SLS Coefficient } \\
\text { Estimates }\end{array}$ & t-stat \\
\hline (1) & $(2)$ & $(3)$ & $(4)$ & $(5)$ \\
Common-Law & $0.462^{* *}$ & 2.39 & 0.666 & 2.06 \\
Low-Income & $-0.856^{* *}$ & -2.91 & -3.582 & -1.10 \\
Mid-Income & $-0.602^{* *}$ & -2.43 & -2.526 & -1.07 \\
Experience & 0.006 & 1.43 & 0.0103 & 1.38 \\
Corruption & $-0.254^{* *}$ & -5.61 & 0.3207 & 0.46 \\
Ln Imports & 0.104 & 0.48 & 0.249 & 0.79 \\
Ln of Size & $0.123^{* *}$ & 2.32 & 0.111 & 1.43 \\
Constant & 1.239 & 1.10 & & \\
r2 & 0.732 & & & \\
Root MSE & 0.52624 & & 0.869 & \\
F-stat & 40.28 & & & \\
Number of observations & 86 & & 83 & \\
\hline
\end{tabular}

Ln represents natural logarithms of the explanatory variable. Standard er; ${ }^{* *}$ represents significance at the $95 \%$ level and *at the $90 \%$ level. 
significant even after the two-stage least squares procedure. This result suggests that competition policies in common-law countries are more likely to perform better than in non-common law countries, all else equal. The result supports the Waller-Newberg hypothesis and is similarly consistent with results of the Law and Finance literature.

The results are not surprising; antitrust is largely a common law doctrine that has been grafted onto traditional civil-law systems. Both legislation as well as the practice of antitrust has been adopted largely intact, causing procedural confusion and difficulties when cases appear for review by the traditional court system and traditional legal practices. The more formal process-driven approach typical of code law countries has enveloped the administration of competition law resulting in considerable procedural delays. In addition, in many countries, where no private cause of action is possible, the actual number of antitrust cases brought by the competition agency is not sufficient to support specialized antitrust practices by the local bar nor is it sufficient to foster the much needed independent commentary by scholars and practitioners; thus, the practice of antitrust remains an isolated, occasional type of event for the local bar.

The corruption variable displays the expected (negative) sign in the ordinary least squares regression indicating that competition agencies perform comparatively better in less corrupt economies. The result in the extended regression may reflect the fact that corruption may affect competition policy performance in part directly and in part indirectly through the legal system.

Surprisingly, experience with competition policy is not statistically significant, effectively explaining little of the variance in performance; this is surprising but not unexplainable. Because competition policy was an entirely novel initiative in many developing countries when it was adopted, there was no baseline against which to compare an agencies' performance. This may in fact be an artifact of the data and survey bias and not necessarily read to suggest that experience does not enhance performance. 
On the other hand, many of the incipient agencies were provided with considerable financial and technical support ensuring above average performance, at least at the outset. In addition, many competition agencies were advised to commence enforcement actions with manageable, relatively uncomplicated cases, to facilitate training and constituency building. The benefit of an experienced staff is best observed in disentangling complex cases; these may be yet to come. To the extent that this latter reasoning is true one would not expect experience to account for any sizable portion of the performance gap. Only a closer examination of the complexity and difficulty of an agency's cases would settle this matter; a study that is best left for another time.

Imports do not appear to have any significance in explaining antitrust performance, perhaps understandably so. No substantive differences were observed in the results by replacing imports either by foreign direct investment flows or by openness, a traditional measure of competitive intensity, nor by including foreign direct investment as an additional explanatory variable in the specified equation [the numerical results were left out to conserve space]. The adoption of competition policies over the last decade has been driven-for the most part-by the general desire of multilateral agencies and donors to ensure good governance in the various incipient market economies.

Antitrust proscriptions and an associated enforcement agency are considered key ingredients for success within this paradigm. Naturally, we observe that the embrace of competition policy is largely removed from the concern over domestic market power abuses associated with poor competitive discipline, attributable in part to the absence of imports. Thus, the presence of competition policy programs and competition policy appraisals are necessarily unrelated to import levels.

Size appears to matter, providing some support for the belief that small economies are more susceptible to price discipline resulting from trade rather than from antitrust enforcement activity. 


\section{Cross-Section Versus Fixed Effects Estimates}

It is a common criticism of cross-sectional studies to question whether the results are biased because the econometrician is unable to observe and control for important differences across jurisdictions and those differences are correlated with performance, the variable whose effect is at issue (Hsiao, 1986). Any unobserved differences not controlled for in the cross-section analysis would explain the performance asymmetry. However, my review of the literature turned up no evidence of important unobservable factors affecting performance other than those present in the analysis above.

An alternative to the omitted variables problem would be to estimate a fixed effects model. This would require assembling a panel data set-a cross-section through time. This approach would have greatly reduced the available nation-count while offering no significant advantage. Importantly, a cursory analysis on the available performance variable reveals that the performance data varied more across nations than it did over time; the correlation between the survey responses for year 2003 and year 2002 (WEF, 2003) was 0.9699 . This persistence is consistent with observations by analysts, who consider governance quality to be substantially constant over relatively short periods of time (Kurtz and Schrank, 2007). Thus, any estimates based on a pooled data set are likely to be dominated by comparisons across markets. Last, econometric testing for the presence of an omitted-variable problem raises no concern; a Ramsey regression specification error test of the null that the extended model above has no omitted variables cannot be rejected.

\section{CONCLUSION}

The emergence of competition policy regimes promises to continue as competition policy codes constitute integral parts of trade agreements, among other factors. The results here suggest that we 
should expect a differential impact in performance of these regimes based on their historical legal tradition as anticipated by the Waller-Newberg hypothesis. Specifically, there is statistically significant evidence that suggests that national legal tradition is a major explanatory variable for competition policy performance, all else equal. The relevance of legal tradition on the observed performance gap must be acknowledged and addressed before further gains can be expected from the novel competition agencies and before further progress can be achieved via multi-jurisdictional cooperation.

Is the bleak prognosis of the Waller-Newberg hypothesis inescapable? Clearly, the above average performance of affluent, civil law nations such as Germany, Japan and Korea holds promise. Banking on causation, USAID and other donors have spent, and continue to spend considerable efforts and monies at judicial reform in developing and transition economies (Messick, 1999; Carothers, 2003). Careful examinations of the results of these programs should be highly dispositive in the ongoing debate about whether legal jurisprudence is merely incidental (Carothers, 2003).

\section{ACKNOWLEDGMENTS}

Malcolm Coate, Lesley DeNardis, Joshua Newberg, Gustav Ranis, Bob Thorpe, and Spencer Waller offered helpful commentary on a previous version of this article; I am grateful to them.

\section{REFERENCES}

Alesina, A. Devleeschauwer, A. Easterly, W. Kurlat, S. and Wacziarg, R. 2003. Fractionalization. Journal of Economic Growth 8: 155-194.

Barro, R. J., and Sala-i-Martin, X. 1992. Convergence. Journal of Political Economy 100: 223-251. 
Boner, R. A. and Krueger, R. 1991. The Basics of Antitrust Policy: A Review of Ten Nations and the European Communities. World Bank Technical Paper No. 160.

Boza, B. 2003. Small Economies and Competition Policy: A Background Paper. OECD Global Forum on Competition, CCNM/GF/COMP(2003)4.

Brezinski, Carolyn. 1994. Competition and Antitrust Law in Central Europe: Poland, the Czech Republic, Slovakia and Hungary. University of Michigan Journal of International Law 15: 1129.

Briguglio, L., and Kaminarides, J. 1993. Islands and Small States: Issues and Policies. World Development 21:193-195.

Carothers, T. 2003. Promoting the Rule of Law Abroad: The Problem of Knowledge. Working Paper No. 34, Carnegie Endowment.

CIA Factbook. www.cia.gov/cia/publications/factbook.

Comanor, W. S. 1982. Antitrust in a Political Environment. The Antitrust Bulletin 32:733.

Davidow, J. and Shapiro, H. 2003. The Feasibility and Worth of a World Trade Organization Competition Agreement. Journal of World Trade 37:49-68.

Dolowitz, D. P., and Marsh, D. 2000. Learning from Abroad: The Role of Policy Transfer in Contemporary Policy Making. Governance: An International Journal of Public Administration 13: 5-24.

Epstein, R. A., and Greve, M. S. 2004. Competition Laws in Conflict. Washington, DC: American Enterprise Institute.

Evans, L. and Hughes, P. 2003. Competition Policy in Small Distant Economies: Some Lessons from the Economics Literature. New Zealand Treasury Working Paper (December).

Fearon, J. D. 2003. Ethnic and Cultural Diversity by Country. Journal of Economic Growth 8: 195-222. 
Fox, E. 2000. Equality, Discrimination, and Competition Law: Lessons from and for South Africa and Indonesia, Harvard International Law Journal 41 (Spring) 579-594.

Fox, E. M. 2003 International Antitrust - A Multi-Tiered

Challenge: The Doha Dome. Virginia Journal of International Law 43:911-932.

Fox, E. M., Sullivan, L. A. and Peritz, R. J. 2004. U.S. Antitrust in Global Context. St. Paul: Thomson, West.

FTAA. http://www.ftaa-alca.org/ngroups/ngcomp_e.asp.

Gal, M. S. 2001. Size Does Matter: The Effects of Market Size on

Optimal Competition Policy. University of Southern California Law Review. 74:1437-1478.

Gal, M. S. 2001. Market Conditions Under the Magnifying Glass:

General Prescriptions for Optimal Competition Policy for Small Market Economics. Draft.

Gellhorn, E., Kovacic, W. E. and Calkins, S. 2004. Antitrust Law and Economics in a Nutshell, Fifth Edition. St. Paul: Thompson-West.

Ghoneim, A. F. 2003. Competition Law \& Competition Policy:

What Egypt Really Needs? Boletin Latinoamericano de Competencia 17:46-58.

Gifford, D. J., and Kudrle, R. T. 2003. European Union Competition Law and Policy: How Much Latitude for Convergence with the United States? Antitrust Bulletin 48: 727-780.

Glaeser, E., LaPorta, R. Lopez-de-Silanes, F. and Shleifer, A. 2004. Do Institutions Cause Growth? Journal of Economic Growth.

Global Competition Forum, www.Globalcompetitionforum.org. Hall, Robert E., \& Jones, C. I. 1999. Why Do Some Countries Produce So Much More Output per Worker Than Others?" Quarterly Journal of Economics 114: 83-116.

Hoekman, B. and Mavroidis, P. C. 2003. Economic Development, Competition Policy and the World Trade Organization. Journal of World Trade 37: 1-27. 
Hsiao, C. 1984. Analysis of Panel Data. Cambridge: Cambridge University Press.

Inside US Trade. "FTC Chairman Says World Competition Rules Currently Not Feasible," (April 26, 1996) 15-16.

Kaufmann, D., Kraay, A. and Mastruzzi, M. 2005. Governance Matters IV: Governance Indicators for 1996-2004. Washington, DC: The World Bank (May).

Kovacic, W. E. 2001. Institutional Foundations for Economic Legal Reform in Transition Economies: The Case of Competition Policy and Antitrust Enforcement. Chicago Kent Law Review 77: 265-315.

Kovacic, W. E. 2001. Evaluating Antitrust Experiments: Using Ex

Post Assessments of Government Enforcement Decisions to Inform Competition Policy. George Mason Law Review 9: 843-861.

Kovacic, W. E. 2003. The Modern Evolution of U.S. Competition Policy Norms. Antitrust Law Journal 71: $377-478$.

Kovacic, W. E., and Shapiro, C. 2000. Antitrust Policy: A Century of Economic and Legal Thinking. The Journal of Economic Perspectives 14 (Winter) 14: 43-60.

Krakowski, M. 2005. Competition Policy Works: The Effect of Competition Policy on the Intensity of Competition - An International Cross Country Comparison. HWWA Discussion Paper No. 332.

Kurtz, M. J., and Schrank, A. 2007. Growth \& Governance: Models, Measures, and Mechanisms, Journal of Politics 69 (2): 538-544.

La Porta, R., Lopez-de-Silanes, F. Shleifer, A. and Vishny, R. W. 1997. Legal Determinants of External Finance. Journal of Finance 52: 1131-1150.

La Porta, R., Lopez-de-Silanes, F. Shleifer, A. and Vishny, R. W. 1998. Law and Finance. Journal of Political Economy 106: $1113-155$. 
La Porta, R., Lopez-De-Silanes, F. Shleifer, A. and Vishny, R. 1999. The Quality of Government. Journal of Law, Economics and Organization 15: 222-79.

Lee, Cassey. 2004. Legal Traditions and Competition Policy. Working Paper, University of Malaysia.

Lee, C. 2004. Model Competition Laws: The World Bank-OECD and UNCTAD Approaches Compared. Draft, University of Malaya.

Levine, R. 2005. Law, Endowments and Property Rights. Journal of Economic Perspectives 19: 61-88.

Mahoney, P. G. 2001. The Common Law and Economic Growth: Hayek Might Be Right. The Journal of Legal Studies 30: 503-525.

Mankiw, G. N., Romer, D. and Weil, D. N. 1992. A Contribution to the Empirics of Economic Growth. Quarterly Journal of Economics 197: 407-437.

Merryman, J. H. 1985. The Civil Law Tradition. Palo Alto, CA: Stanford University Press.

Newberg, J. 1994. Mexico's New Economic Competition Law: Toward the Development of a Mexican Law of Antitrust. Columbia Journal of Transnational Law 31: 587-609.

OECD. 1998. Recommendation of the Council Concerning Effective Action Against Hard Core Cartels (adopted by the Council at its 921st Session on 25 March 1998 [C/M(98)7/ PROV]).

OECD. 2002. Global Forum on Competition, The United States Experience in Competition Law Technical Assistance: A Ten Year Perspective, CCNM/GF/COMP/WR(2002)20.

Palim, M. 1998. The Worldwide Growth of Competition Law: An Empirical Analysis. The Antitrust Bulletin (Spring) 43:105-145.

Pitofsky, R. 1979. The Political Content of Antitrust. The University of Pennsylvania Law Review 127: 1051. 
Posner, R. A. 1992. Economic Analysis of Law. Boston: Little, Brown.

Posner, R. 1998. Creating a Legal Framework for Economic Development. World Bank Research Observer 13: 1-11.

Priest, G. C. 1977. The Common Law Process and the Selection of Efficient Rules. The Journal of Legal Studies.

Richardson, J. D. and Graham, E. M. 1997. Global Competition Policy. Washington, DC: Institute for International Economics.

Rodrîguez, A. E., and Williams, M. D. 1995. Economic Liberalization and Antitrust in Mexico. Revista de Análisis Económico, Suplemento Especial.

Rubin, P. H. 1977. Why Is the Common Law Efficient? Journal of Legal Studies.

Scherer, F. M. 1994. Competition Policies for an Integrated World Economy. Washington, DC: Brookings Institution.

Schuck, P. H., and Litan, R. E. 1986. Regulatory Reform in the Third World: The Case of Peru. Yale Journal of Regulation 4: 51-78.

UNCTAD. 2004a. A Report on UNCTAD's Capacity Building and Technical Assistance Programme. New York and Geneva: United Nations.

UNCTAD. 2004b. Model Law on Competition (Geneva, 2000).TD/RBP/CONF.5/7.

United States Federal Trade Commission and the Antitrust Division of the U.S. Department of Justice. 2002. The United States Experience in Competition Law Technical Assistance: A Ten Year Perspective. OECD Forum on Competition, CCNM/GF/COMP/WD(2002)20.

Wacziarg, R. and Welch, K. H. 2003. Trade Liberalization and Growth: New Evidence. Research Paper No. 1826, Stanford Graduate School of Business (November).

Waller, S. W. 1994. Neo-Realism and the International Harmonization of Antitrust Law: Lessons from Antitrust. University of Kansas Law Review 42: 557. 
World Economic Forum. 2003. Global Competitiveness Report, 2002-03. Oxford: Oxford University Press.

World Economic Forum. 2004. Global Competitiveness Report, 2003-04. Oxford: Oxford University Press.

World Trade Organization. 2004. World Trade Report. Geneva: World Trade Organization.

\section{DATA APPENDIX}

\section{Sources of Data, Description and Treatment of Variables}

Data on the Effectiveness of Antitrust Policy are from the 2003-04 issue of the Global Competitiveness Report published by the World Economic Forum (World Economic Forum, 2004). The variable Effectiveness of Antitrust Policy is labeled PERFORMANCE in the model; data is available for 102 nations. Because of control variable data limitations, the final two-stage least squares is reduced to 82 nations.

Data on national legal tradition is taken from Lee (2004), Mahoney (2001), the World Bank (http://www.worldbank.org) and the CIA Factbook (http://www.cia.gov/cia/publications/ factbook ). As in Mahoney (2001), non-common law countries were collapsed into one single set; indeed, drawing a distinction between the civil-law subfamilies appears to be a post-hoc rationalization. In fact, because most of the civil-law subfamily countries are in economically-advanced Western Europe, treating them together, contained within the non-common law group, entails a bias that makes the civil-law look better. Accordingly, COMMON LAW is a binary variable controlling whether a nation is characterized by the common law.

Data on Gross Domestic Product per Capita (Foreign Direct Investment, openness, size, and population are from the World Bank's World Development Indicators online database. OPEN represents the sum of exports and imports as a percent of gross national product. SIZE is surface area in square kilometers; 
foreign direct investment (FDI) represents net inflows as a percent of GDP, population (POP) represents total population. But for dummy variables, all variables were transformed into logarithms.

Income level grouping binary variables were derived from the gross national product per capita data as is used in the Global Competitiveness Report (2003-2004): 4000 < LOW INCOME; $4000<=$ MIDDLE INCOME $<17000 ; 17000<=$ HIGHINCOME.

Regional groupings (AFRICA, ASIA, \& MIDDLE EAST, Latin America-LATAM, EUROPE) are all based on the groupings in www.globalcompetitionforum.org; countries in the OECD grouping are OECD members; any European country in the OECD group was excluded from the EUROPE grouping (countries from other regions were treated in the same manner).

Data on the "inaugural" date of competition legislation is from Lee, the Global Competition Forum online database and the Inventory of Domestic Laws and Regulations relating to Competition Policy in the Western Hemisphere, FTAA Negotiating Group on Competition Policy and Prepared by the Tripartite Committee of the Organization of American States, Trade Unit (FTAA.ngcp/inf/03/Rev.2 March 22, 2002) http:// www.ftaa-alca.org/ngroups/NGCP/Publications/DomLaws_e.asp. We updated the list of countries in Lee by adding the following countries: Angola (Cotonou), Antigua \& Barbuda, Barbados, Benin (Cotonou), Bolivia (Constitutional provision), Bostwana (Cotonou), Cameroon, Cote D'Ivoire was changed from 1978 to 1991, Dominican Republic (Constitutional proscription) Ecuador (Constitutional provision), El Salvador (Constitutional provision), Egypt (EuroMediterranean Agreement, June 2000), Ethiopia (Cotonou), Gambia (Cotonou), Greece, Honduras (Constitutional provision), Hong Kong (Telecomm prohibitions), Jordan, Macedonia, Madagascar (Cotonou), Malaysia (various other laws have 
competition elements), Namibia, New Zealand, Nicaragua (Electric Sector Law, Telecom Law, Financial Sector Law), Nigeria (Cotonour), Paraguay (Constitutional provision), Phillipines (Constitutional provisions), Serbia, Singapore, Trinidad \& Tobago (other laws), Uganda (Cotonou), Ukraine, Uruguay, Vietnam, Cotonou entered into force on April 1, 2003. Competition legislation in some countries is found in constitutional proscriptions, in sectoral legislation or in treaty agreements. Thus, the parenthetical associated with the list of countries above alludes to the particular source of the competition law. EXPERIENCE represents a nation's experience with competition law, in years. It is calculated as of 2004; thus, a nation that inaugurated a competition law in 2003 will have one year of experience.

Two data sets measuring Corruption (the variable CORRUPTION) were used at the outset: Transparency International's Corrupt Practices Index and the Global Competitiveness Report, various years, published by the World Economic Forum; Table 7.09, Business Costs of Corruption. Results are consistent and independent of the particular index used. Corruption data was inverted by multiplying by $(-1)$ to facilitate their intuitive interpretation by associating increases in corruption with an increasing scale. We use the Transparency International data set in our empirical work; no meaningful differences emerged when using the alternative data set.

Two data sets on ethnic fractionalization (ETHNIC) are used: James D. Fearon, "Ethnic and Cultural Diversity by Country," Journal of Economic Growth, Volume 8 (2003) 195222, and Alberto Alesina, Arnaud Devleeschauwer, William Easterly, Sergio Kurlat and Romain Wacziarg, "Fractionalization," Journal of Economic Growth, Volume 8 (2003) 155-194. We use the Alesina et al. data set in our empirical work; no meaningful differences emerged when using the alternative set. 
Table VI

Country and Legal Tradition

\begin{tabular}{|c|c|c|c|c|c|}
\hline \multirow{3}{*}{$\begin{array}{l}\text { English } \\
\text { Common Law }\end{array}$} & \multicolumn{2}{|c|}{ French Civil Law } & \multirow{2}{*}{$\begin{array}{c}\text { German } \\
\text { Civil Law } \\
\text { Austria }\end{array}$} & \multirow{2}{*}{$\frac{\text { Socialist Law }}{\text { Armenia }}$} & \multirow{2}{*}{$\begin{array}{c}\begin{array}{c}\text { Nordic } \\
\text { Law }\end{array} \\
\text { Denmark }\end{array}$} \\
\hline & Albania & Madagascar & & & \\
\hline & Algeria & Mali & $\begin{array}{l}\text { Bosnia \& } \\
\text { Herzegovina }\end{array}$ & Azerbaijan & Finland \\
\hline Botswana & Angola & Mauritania & Bulgaria & Belarus & Norway \\
\hline Canada & Argentina & Mexico & China & Georgia & Sweden \\
\hline Ethiopia & Belgium & Morocco & Croatia & Kazahkstan & 4 \\
\hline Fiji & Benin & Mozambique & Czech Rep & Kyrgyz Rep & \\
\hline Ghana & Bolivia & Netherlands & Estonia & Moldova & \\
\hline Hong Kong & Brazil & Nicaragua & Germany & Mongolia & \\
\hline Iceland & Burkina Faso & Niger & Hungary & Russia & \\
\hline India & Burundi & Oman & Japan & Tajikistan & \\
\hline Iran & Cambodia & Panama & Korea & Ukraine & \\
\hline Ireland & Cameroon & Paraguay & Latvia & Uzebkistan & \\
\hline Israel & $\begin{array}{l}\text { Central African } \\
\text { Republic }\end{array}$ & Peru & Macedonia & 12 & \\
\hline Jamaica & Chad & Phillipines & Poland & & \\
\hline Kenya & Chile & Portugal & $\begin{array}{l}\text { Serbia \& } \\
\quad \text { Montenegro }\end{array}$ & & \\
\hline Lesotho & Colombia & Puerto Rico & Slovak Rep & & \\
\hline Malawi & Congo (DR) & Romania & Slovenia & & \\
\hline Malaysia & Congo (Rep) & Rwanda & Switzerland & & \\
\hline Malta & Costa Rica & Senegal & Taiwan & & \\
\hline Namibia & Cote d'Ivoire & Spain & 19 & & \\
\hline Nepal & $\begin{array}{r}\text { Dominican } \\
\text { Republic }\end{array}$ & Syria & & & \\
\hline New Zealand & Ecuador & Togo & & & \\
\hline Nigeria & Egypt & Tunisia & & & \\
\hline Pakistan & El Salvador & Turkey & & & \\
\hline $\begin{array}{c}\text { Papua New } \\
\text { Guinea }\end{array}$ & France & Uruguay & & & \\
\hline Saudi Arabia & Gabon & Venezuela & & & \\
\hline Sierra Leone & Greece & Vietnam & & & \\
\hline Singapore & Guatemala & & & & \\
\hline South Africa & Guinea & & & & \\
\hline Sri Lanka & Haiti & & & & \\
\hline Tanzania & Honduras & & & & \\
\hline Thailand & Indonesia & & & & \\
\hline Uganda & Italy & & & & \\
\hline
\end{tabular}


Table VI

(Continued)

\begin{tabular}{|c|c|c|c|c|}
\hline $\begin{array}{l}\text { English } \\
\text { Common Law }\end{array}$ & French Civil Law & $\begin{array}{c}\text { German } \\
\text { Civil Law }\end{array}$ & Socialist Law & $\begin{array}{c}\text { Nordic } \\
\text { Law }\end{array}$ \\
\hline $\begin{array}{c}\text { United Arab } \\
\text { Emirates }\end{array}$ & Jordan & & & \\
\hline $\begin{array}{l}\text { United } \\
\text { Kingdom }\end{array}$ & Kuwait & & & \\
\hline United States & Laos & & & \\
\hline Yemen & Lebanon & & & \\
\hline Zambia & Lithuania & & & \\
\hline Zimbabwe & Luxembourg & & & \\
\hline & 39 & & & \\
\hline 39 & 66 & & & \\
\hline
\end{tabular}

Table VII

Summary

\begin{tabular}{ll}
\hline English Common Law & 39
\end{tabular}

French Civil Law $\quad 66$

$\begin{array}{lr}\text { German Civil Law } & 19\end{array}$

Socialist Law 12

Nordic Law 4

$\begin{array}{lr}\text { Total } & 140\end{array}$

\section{TESTING FOR SIMULTANEITY}

Corruption perceptions may be either imperfectly measure or simultaneously determined with the performance variable; that is to say, it may suffer from attenuation bias as well as simultaneity bias. If either of these conditions are present ordinary least squares may be an inconsistent estimator. Formally, is the covariance between corruption and the error term not equal to 0 ? In this section we test for the presence of a correlation between the corruption perceptions index used in the model and the error term to determine the appropriate estimation procedure. 
The null is $\mathrm{H}_{0}: \operatorname{cov}(\mathrm{CORRUPTION}, \mathrm{e})=0$ and the alternative is $\mathrm{H}_{1}: \operatorname{cov}(\mathrm{CORRUPTION}$, e) 0 . Naturally, if the null hypothesis is true, we use the least squares estimator. If the null hypothesis is not true, we use the instrumental variables estimator.

Data on ethnic fractionalization (ETHNIC) is used as an instrument for CORRUPTION. Several authors have argued: societies that are ethnically or linguistically fractionalized are more likely to have corrupt governments; bureaucrats under these regimes may be more prone to single out and favor their own ethnic groups (La Porta et al., 1999; Alesina et al. 2003; Fearon, 2003). Since the percentage of a nation's ethnic fractionalization is to a large extent determined historically and often established in colonial times, thus it is unlikely that ethnic fractionalization (ETHNIC) will be correlated with the disturbance in the competition agency performance model.

The ordinary least squares results of estimating a linear model between CORRUPTION and ETHNIC are presented below:

Table VIII

OLS Results

\begin{tabular}{lcr}
\hline Explanatory Variable & Coefficient Estimates & t-stat \\
\hline$(1)$ & $(2)$ & $(3)$ \\
Constant & $-5.847^{* *}$ & -14.44 \\
ETHNIC & $3.939^{* *}$ & 4.83 \\
r2 & 0.1592 & \\
F-stat & 23.29 & \\
Number of observations & 125 & \\
\hline
\end{tabular}

The model residuals (VHAT) are used as an explanatory variable in the extended competition policy performance model discussed in the text above; the results are presented in the table below: 
Table IX

OLS Results: Simultaneity Results

\begin{tabular}{lcr}
\hline Explanatory Variable & OLS Coefficient Estimates & t-stat \\
\hline$(1)$ & $(2)$ & $(3)$ \\
Common-Law & $0.428^{* *}$ & 2.60 \\
Low-Income & $-1.028^{* *}$ & -3.30 \\
Mid-Income & $-0.675^{* *}$ & -2.90 \\
Experience & 0.006 & 1.57 \\
Corruption & $-0.151^{* *}$ & -1.69 \\
Ln Imports & 0.095 & 0.57 \\
Ln of Size & $0.132^{* *}$ & 2.76 \\
VHAT & -0.106 & -1.31 \\
\hline Constant & 1.681 & 1.38 \\
\hline r2 & 0.731 & \\
Root MSE & 0.52968 & \\
F-stat & 25.74 & \\
Number of observations & 83 & \\
\hline
\end{tabular}

Ln represents natural logarithms of the explanatory variable. ${ }^{*}$ represents significance at the $95 \%$ level and *at the $90 \%$ level.

Where the coefficient on VHAT is shown to be not significantly different from zero. Thus, we cannot reject the null hypothesis that the variable CORRUPTION and the error term are uncorrelated. The outcome of this test provides some support for the robustness of ordinary least squares estimates of the model coefficients. 